\title{
Effect of Feeding Rice based Brewer's by Product "Juglee" on Growth and Haematological Parameters of Hampshire X Assam Local Grower Pigs
}

\author{
Mridushmita Sonowal ${ }^{1}$, M. Sarma ${ }^{1}$, D. Bharali ${ }^{1}$, P. Boro ${ }^{1}$, J. Brahma ${ }^{1}$ and P. Borah ${ }^{2 *}$ \\ ${ }^{1}$ Livestock Research Station, Assam Agricultural University, \\ Mandira, Kamrup (R), Assam, India \\ ${ }^{2}$ Goat Research Station, Assam Agricultural University, Barnyhat, Assam, India \\ *Corresponding author
}

\section{A B S T R A C T}

\section{Keywords}

Juglee, Grower pig,

Growth,

Haematological

parameters

Article Info

Accepted:

10 January 2021

Available Online:

10 February 2021
Twenty four (Hamshire x Assam local) grower pigs of about 3 months of age and body weight ranged from $13.2 \pm 0.60$ to $13.8 \pm 0.60$ of either sex were divided into four groups using randomized block design. Four different diets were prepared for feeding the animals viz, $\mathrm{T}_{0}$ - Standard grower ration without rice based brewer's byproduct (juglee) (basal diet), $\mathrm{T}_{1}-85 \%$ basal diet with $15 \%$ juglee, $\mathrm{T}_{2}-70 \%$ basal diet with $30 \%$ juglee and $\mathrm{T}_{3}-55 \%$ basal diet with $45 \%$ juglee. The mean total body weight gain of the experimental animals were ranged from $17.1 \pm 0.83$ to $23.9 \pm 1.21$, which was significantly $(\mathrm{P}<0.05)$ lower in group $\mathrm{T}_{3}$. The mean total feed intake was significantly different $(\mathrm{P}<0.05)$ among the groups. The FCR was not different among the groups but, average daily gain was significantly $(\mathrm{P}<0.05)$ lower in $\mathrm{T}_{3}$ group. The cost per $\mathrm{kg}$ body weight gain (Rs) was decreased gradually along with the increased incorporation of juglee in the diets. The haematological parameters were within the normal range in each group after the feeding trial. From this study, it can be concluded that, rice based brewer's byproduct (juglee) can be incorporated in the diet of grower pigs upto $30 \%$ level with better growth and distinct economic advantage.

\section{Introduction}

Pigs are traditionally reared by the tribal population of North East India and it has the potential to act as a change-agent of the rural economy. The market demand of pork is very huge as more than 75 per cent of the population consume pork. Intensification of agricultural farming system has led the erstwhile traditional scavenging system of pig rearing to transform into semi-intensive or intensive system of pig farming. This transformation is labour and input intensive resulted in higher cost of production especially the feed cost. Searching for low cost and easily available alternative feed ingredients to minimize the cost of feeding has appeared as the need of the hour. Incorporation of locally available unconventional feed may be one of the solutions to reduce feed cost. Rice beer is a traditional beverage prepared by the native 
tribal people of north east region. The byproduct called "juglee" is generally offered to pigs on random basis along with other feed ingredients. Balancing the feed ingredients by incorporating the juglee may have effect on growth performance and reducing feed cost, which will add-on the farmer's profit. Hence, the present work was taken up to access the effect of feeding locally available rice based brewer's by-products "juglee" on growth and haematological parameters of Hampshire X Assam Local grower pigs.

\section{Materials and Methods}

Twenty four (24) crossbred (Hampshire X Assam local) grower pigs of about 3 months age were selected from the piggery farm of Livestock Research Station, Assam Agricultural University, Mandira for conducting a feeding experiment for 90 days. The piglets were randomly allotted to 4 treatment groups (Group $\mathrm{T}_{0}, \mathrm{~T}_{1}, \mathrm{~T}_{2}$ and $\mathrm{T}_{3}$ ) having 6 numbers in each treatment in a Randomized Block Design (RBD). The groups were allotted the experimental diets with rice based brewer's byproduct (juglee), which were collected from nearby villages, as follows-

Group $\mathrm{T}_{0}$ (Control): $100 \%$ basal diet $+0 \%$ juglee

Group $\mathrm{T}_{1}: \quad 85 \%$ Basal diet $+15 \%$ juglee

Group $\mathrm{T}_{2}: \quad 70 \%$ Basal diet $+30 \%$ juglee

Group $\mathrm{T}_{3}: \quad 55 \%$ Basal diet $+45 \%$ juglee

The basal diet (Table 1) was prepared as per the recommendation of ICAR (2013) and the experimental pigs were reared as per the standard managemental practice. The live body weight of the experimental pigs was recorded weekly in the morning hours before offering feed and water. The feed intake $(\mathrm{kg})$ was recorded daily and fresh wholesome drinking water was made available throughout the day. Blood samples $(1.5 \mathrm{ml})$ were collected in an anticoagulant coated vacutainer for estimating the haematological parameters at the end of the experiment following standard procedure.

The statistical analysis of the experimental data was carried out by using Statistical Package for Social Science (SPSS) version 23.0.

\section{Results and Discussion}

The mean final body weight $(\mathrm{kg})$, total body weight gain $(\mathrm{kg})$, feed intake $(\mathrm{kg})$, average daily body weight gain (g), feed conversion ratio and cost of feed per $\mathrm{kg}$ weight gain is presented in Table 2. The mean total body weight gain of the experimental pigs are ranged from $17.1 \pm 0.83$ (Group $\mathrm{T}_{3}$ ) to $23.90 \pm$ 1.21(Group $\mathrm{T}_{0}$ ), where the group $\mathrm{T}_{3}$ is significantly $(\mathrm{P}<0.05)$ different from the other three groups $\left(T_{0}, T_{1}\right.$ and $\left.T_{2}\right)$. The mean total feed intake of the experimental animals were $74.30 \pm 0.75,71.4 \pm 0.46,69.6 \pm 0.53$ and $60.4 \pm 0.51$ in group $\mathrm{T}_{0}, \mathrm{~T}_{1}, \mathrm{~T}_{2}$ and $\mathrm{T}_{3}$ respectively, which differs significantly $(\mathrm{P}<0.05)$ among each other. The average daily gain $(\mathrm{g})$ of the animals in different treatment groups were $265.60 \pm 13.58,246.8 \pm 13.24$, $235.2 \pm 6.39$ and $189.8 \pm 9.13$ in $\mathrm{T}_{0}, \mathrm{~T}_{1}, \mathrm{~T}_{2}$ and $\mathrm{T}_{3}$ group respectively. The group $\mathrm{T}_{3}$ is significantly $(\mathrm{P}<0.05)$ different from other three groups (group $\mathrm{T}_{0}, \mathrm{~T}_{1}$ and $\mathrm{T}_{2}$ ). Barman at el (2020) also reported similar result with grower pigs when fed with three different levels of brewers' rice by-product. Growing pigs fed with locally made rice beer waste upto 25 per cent of the total dry matter showed an increased average daily gain and feed conversion efficiency as compared to pigs that offered conventional concentrate diet and diet with rice beer upto 50 per cent of the total dry matter (Haldar et al., 2017). The feed conversion ratios (FCR) were $3.14 \pm$ $0.15,3.25 \pm 0.18,3.29 \pm 0.10$ and $3.56 \pm 0.19$ 
in $\mathrm{T}_{0}, \mathrm{~T}_{1}, \mathrm{~T}_{2}$ and $\mathrm{T}_{3}$ group respectively. The values of feed conversion efficiency are not statistically different among the groups. Konia et al., (2017) reported no significant difference on average daily gain, feed intake and feed conversion ratio among the different groups of pigs which were fed with diets containing 0,10 and 20 per cent of distillers dried grain soluble (Fig. 1).

Table.1 Composition and nutritive value of the basal diet

\begin{tabular}{|l|c|}
\hline \multicolumn{1}{|c|}{ Ingredients } & Parts $(\boldsymbol{\%})$ \\
\hline Maize & 60 \\
\hline Wheat bran & 5 \\
\hline Rice polish & 5 \\
\hline GNC & 17 \\
\hline FM & 10 \\
\hline Min mix & 2 \\
\hline Common & 1 \\
Salt & 18.17 \\
\hline CP $(\%)$ & 3033.00 \\
\hline ME(Kcal/Kg) & \\
\hline
\end{tabular}

Table. 2 Growth parameters of the experimental pigs and cost of feed per $\mathrm{kg}$

\begin{tabular}{|l|c|c|c|c|}
\hline \multirow{2}{*}{ Parameters } & \multicolumn{4}{|c|}{ Groups } \\
\cline { 2 - 5 } & $\mathrm{T}_{0}$ & $\mathrm{~T}_{1}$ & $\mathrm{~T}_{2}$ & $\mathrm{~T}_{3}$ \\
\hline Initial body weight $(\mathbf{K g})$ & $13.70 \pm 0.66$ & $13.80 \pm 0.60$ & $13.2 \pm 0.60$ & $13.4 \pm 0.58$ \\
\hline Final body weight $(\mathbf{k g})$ & $37.60^{\mathrm{a}} \pm 0.81$ & $36.00^{\mathrm{ab}} \pm 0.81$ & $37.6^{\mathrm{a}} \pm 0.81$ & $34.40^{\mathrm{b}} \pm 0.43$ \\
\hline Total body weight gain(kg) & $23.90^{\mathrm{a}} \pm 1.21$ & $22.2^{\mathrm{a}} \pm 1.19$ & $21.2^{\mathrm{a}} \pm 0.56$ & $17.1^{\mathrm{b}} \pm 0.83$ \\
\hline Feed intake (kg) & $74.30^{\mathrm{a}} \pm 0.75$ & $71.4^{\mathrm{b}} \pm 0.46$ & $69.6^{\mathrm{c}} \pm 0.53$ & $60.4^{\mathrm{d}} \pm 0.51$ \\
\hline Average daily weight gain $\mathbf{( g )}$ & $265.60^{\mathrm{a}} \pm 13.58$ & $246.8^{\mathrm{a}} \pm 13.24$ & $235.2^{\mathrm{a}} \pm 6.39$ & $189.8^{\mathrm{b}} \pm 9.13$ \\
\hline FCR & $3.14 \pm 0.15$ & $3.25 \pm 0.18$ & $3.29 \pm 0.10$ & $3.56 \pm 0.19$ \\
\hline $\begin{array}{l}\text { Cost of feed per kg weight } \\
\text { gain (Rs) }\end{array}$ & 94.20 & 86.87 & 78.96 & 74.76 \\
\hline
\end{tabular}

Table.3 Haematological parameters in different groups

\begin{tabular}{|l|c|c|c|c|c|}
\hline Parameters & $\mathbf{T}_{\mathbf{0}}$ & $\mathbf{T}_{\mathbf{1}}$ & $\mathbf{T}_{\mathbf{2}}$ & $\mathbf{T}_{\mathbf{3}}$ & Normal values \\
\hline RBC $(\mathbf{x 1 0} / \boldsymbol{\mu l})$ & $7.06 \pm 0.31$ & $7.25 \pm 0.45$ & $7.15 \pm 0.89$ & $7.11 \pm 0.78$ & $5-7$ \\
\hline WBC $(\mathbf{x 1 0} / \boldsymbol{\mu l})$ & $11.15 \pm 0.65$ & $11.85 \pm 0.55$ & $11.98 \pm 0.45$ & $11.78 \pm 0.76$ & $11-22$ \\
\hline HGB $(\mathbf{g} / \mathbf{d l})$ & $12.45 \pm 0.88$ & $12.98 \pm 0.48$ & $12.11 \pm 0.55$ & $12.75 \pm 0.23$ & $9-13$ \\
\hline HCT $(\%)$ & $37.45 \pm 0.66$ & $38.11 \pm 0.75$ & $37.98 \pm 0.65$ & $37.76 \pm 0.77$ & $36-43$ \\
\hline MCH $(\mathbf{p g})$ & $18.45 \pm 0.77$ & $18.12 \pm 0.85$ & $18.65 \pm 0.11$ & $18.55 \pm 0.64$ & $17-24$ \\
\hline PLT $(\mathbf{x 1 0} / \boldsymbol{\mu l})$ & $394.5 \pm 1.21$ & $385.44 \pm 2.11$ & $395.85 \pm 1.15$ & $397.55 \pm 0.44$ & $200-500$ \\
\hline
\end{tabular}


Fig.1 Graphical representation of body weight gain of the experimental pigs

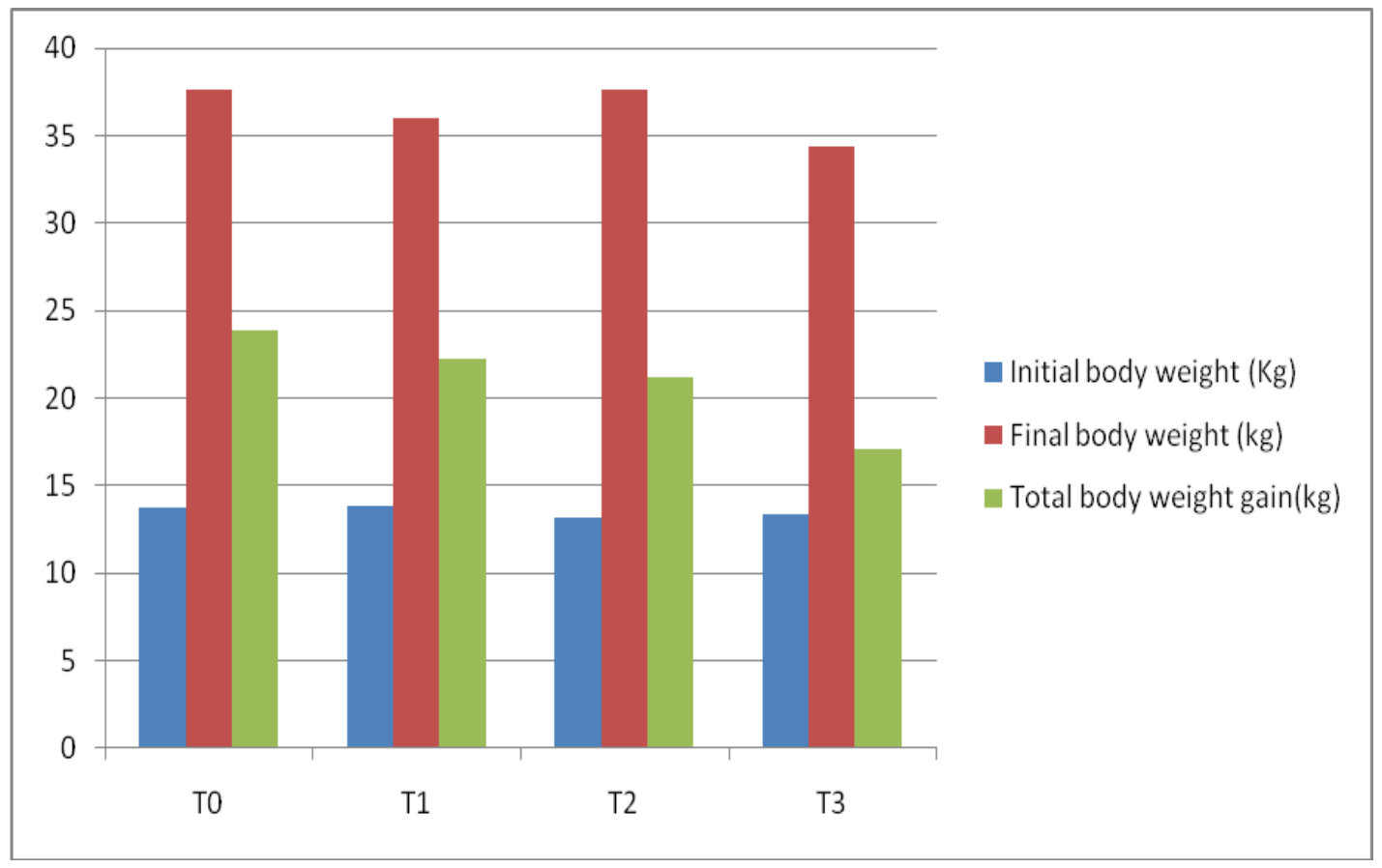

The cost of feed per kg weight gain (Rs) indicated that with the increased level of juglee in the diet, the cost of feed gradually decreased (Rs 94.2, Rs 86.87, Rs 78.96 and Rs 74.76 in $\mathrm{T}_{0}, \mathrm{~T}_{1}, \mathrm{~T}_{2}$ and $\mathrm{T}_{3}$ group respectively) which may be due to the higher incorporation of low cost feed ingredient.

The values of the haematological parameters (Table 3) like RBC (x10 $/ \mu 1)$, WBC $\left(\times 10^{3}\right.$ $/ \mu \mathrm{l})$, HGB $(\mathrm{g} / \mathrm{dl}), \mathrm{HCT}(\%), \mathrm{MCH}(\mathrm{pg})$ and PLT $\left(\times 10^{3} / \mu \mathrm{l}\right)$ of the pigs of different experimental groups estimated at the end of the experiment are within the normal range (Merck Veterinary Manual, 2005.). Konia et al (2017) also reported normal values of haematological parameters of pigs which were fed with diets containing different levels of distillers dried grain soluble.

The results from the present study showed that the rice based brewer's by-product "juglee" can be incorporated in the diet of Hampshire X Assam local grower pigs upto the level of 30 per cent of conventional concentrate diet with better growth performance and distinct economic advantage.

\section{References}

Barman, K., Banik, S., Thomas, R., Gokuldas, P., Kaushik, P., Das, B., Das, A., Konwar, D. And Rajkhowa, S. 2020. Effect of replacing conventional diet with brewer's rice byproduct on performance of crossbred (Hampshire x Assam local) grower pigs. Indian Journal of Animal Health. $59: 62$.

Halder, A., Das, D., Santra, A., Pal, P., Dey, S., Das, A., Rajkhowa, D., Hazarika, S., Datta, M. 2017. Traditional feeding system for pigs in Northeast India. International Journal of Livestock Research 7(8): 122-132

ICAR (2013): Nutrient Requirement of Swine. Indian Council of Agricultural Research. Third Edition, New Delhi.

Konia, T., Mahendar, M., Nalini Kumari, N., Borah, B., Debbarman, C. And 
Borthakur, C. 2017. Effect of feeding DDGS (Dried Distillers grains with soluble) in the growth and haematological parameters of crossbred piglets.
International Journal of Educational Science and Research. 7(2): 31-34

The Merk Veterinary Manual, 2005. Ninth edition

\section{How to cite this article:}

Mridushmita Sonowal, M. Sarma, D. Bharali, P. Boro, J. Brahma and Borah, P. 2021. Effect of Feeding Rice based Brewer's by Product "Juglee" on Growth and Haematological Parameters of Hampshire X Assam Local Grower Pigs. Int.J.Curr.Microbiol.App.Sci. 10(02): 1056-1060. doi: https://doi.org/10.20546/ijcmas.2021.1002.124 